\title{
Overview of Public Policy in Improving Tourism at Kelapa Tuban Beach
}

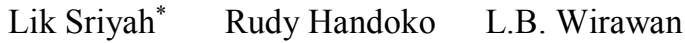 \\ Faculty of Social Science and Political Science, University of 17 Agustus 1945, Indonesia
}

\begin{abstract}
The tourism sector is one of the priority sectors in development in Indonesia. Law No. 10 of 2009 describes local governments' role in managing resources through tourism based on these regulations. Tuban Regency must maximise the authority given to the welfare of its communities by managing its potential. One of them is maximising management in the tourism sector, such as coconut beach tourism. This research used a qualitative method. The type of data used as primer data is collected through interviews. Data analysis techniques used are qualitative data analysis. This study shows that the implementation of Tuban Beach Tourism Development policy has been implemented well supported by clear and consistent communication. Support for adequate human resources in quantity and quality and adequate infrastructure resources, but budget resources show not maximum. It is only obtained from ticket/entrance tickets, parking money, and kiosk rental in Kelapa Beach. The parties involved are firmly committed and willing to be involved in implementing The Coconut Beach development. The implementers or related parties involve the community in developing Tuban Beach tourism by providing opportunities to open businesses around the beach. The organisational structure has been well organised with the support of SOP running by the planned procedures.
\end{abstract}

Keywords: Policy Implementation, Tourism Development, Public Policy

DOI: $10.7176 / \mathrm{PPAR} / 11-2-05$

Publication date:March $31^{\text {st }} 2021$

\section{Introduction}

\subsection{Background}

Indonesia is an archipelago with two-thirds of its territory composed of territorial waters (Fadelan, Darmawan and Widodo, 2020). Indonesia has more than 17,000 islands divided into 514 cities/regencies. The central government has granted regional autonomy in Law No. 29 of 1999 to manage the district/ city resources. One way to improve the economy of the area is with tourism. Tourism is one of the potentials that are now widely excavated and developed in many countries. Law No. 10 of 2009 on Tourism states that tourism is an integral part of National Development carried out systematically, planned, integrated, sustainable, and responsible while providing protection of religious values, living culture in the community, sustainability and quality of the environment national interests. That is why tourism needs to be built and developed effectively in a Country.

The tourism sector is one of the priority sectors in development in Indonesia today because it has a tremendous prospect to be developed (Pitana and Gayatri, 2005). Especially for regions in Indonesia that hold abundant and diverse natural and cultural potential, which deserves to be developed as a tourist attraction, including in Tuban Regency. Tuban Regency is located in the northern part of Java island. It becomes the westernmost region of East Java province, which becomes the border with the city of Rembang in Central Java. A coastline that stretches throughout Tuban district with a length of 65-kilometres becomes the potential of Tuban district in improving its tourism sector through the coast.

Law No. 10 of 2009 on Tourism regulates the opportunities for utilising and developing tourism resources responsible for all relevant parties, especially local government agencies responsible for each asset and regional resources. Law No. 10 of 2009 describes the role of local governments in managing resources through tourism explicitly. Tourism is included in the sector that improves the community's welfare (Karnadjaja et al., 2020). Based on these regulations, Tuban Regency must maximise the authority given to its community's welfare by managing its potential. One of them is maximising management in the tourism sector. Tuban Regency has several marine-tourism that can be developed: Coconut Beach Tourism, Boom Beach Tourism, and Nglirip Waterfall Tourism. Of the three tourist attractions, itis not yet seen local governments' role in developing existing potentials. If the tourism sector increases, it will open new roads to improving the economy of the area around tourism. Therefore, researchers are interested to know the development of tourism in the three locations, finding models in developing tourism potential through public policy.

The importance of tourism development in the Tuban Regency, especially on Kelapa Beach, demands policy improvements to increase Kelapa Beach's tourism potential. The existing policy can be continuously improved to improve the image of the beach position. Also, implementing the policies can help lift traders' economy that is selling in the tourist area. According to George (Edwards, 1980), four components become components of implementing public policy: communication, resources, disposition, and bureaucratic structure. 


\subsection{Problem Formulation}

1. How is the implementation of the tourism development policy of Kelapa Panyuran Beach in the Tuban Regency?

2. What is the tourism development model of Kelapa Panyuran Beach in the Tuban Regency that can empower the region's economy?

\subsection{Research Objectives}

1. To find out the implementation of the tourism development policy of Kelapa Panyuran Beach in Tuban Regency.

2. To know the tourism development model of Kelapa Panyuran Beach in Tuban Regency that can empower the region's economy.

\section{The Foundation of Theory}

\subsection{Implementation}

Implementation is an action carried out by the government and private sector, both individually and in groups, to achieve the goals that have been formulated. In contrast, according to Nugroho, implementation is, in principle, a way to achieve the desired goals (Nugroho, 2017). Implementation is a principle of action or way performed by an individual or group of people to achieve a goal that has been formulated.

Mazmanian and Sebastian in (Wahab, 2015) also define implementation as the implementation of necessary policy decisions, usually in the form of laws, but can also take the form of critical executive orders or decisions or judicial decision bodies. This understanding means that the implementation is implementing necessary policies in the form of laws of essential orders or decisions of the judiciary. After going through a certain number of stages, such as the legal ratification stage, this implementation process occurs, then the policy output in decision implementation until the policy's improvement in question.

According to (Mulyadi, 2015), implementation is an actions to get the goals set out in a decision. This has the purpose of turning these decisions into operational patterns and achieving large or small changes as previously decided. Implementation is also essentially an effort to understand what should happen after the program is implemented. Grindle in (Mulyadi, 2015) defines that implementation as a general administrative action process at a particular program level. Then Gordon in (Mulyadi, 2015) stated the implementation concerning various activities directed at realising the program.

\subsection{Public Policy}

Anderson to (Winarno, 2012) formulated the policy as a deliberate step by an actor or several actors regarding a particular problem or problem faced. Furthermore, Rose in (Winarno, 2012) also suggested that the policy should have a meaning as a series of activities with little to do with the consequences for those concerned rather than stand-alone decisions. The two experts' opinions can explain that interchanging the term policy with a decision is wrong. The policy is understood as a direction or pattern of activity and not just deciding to do something.

Pressman and Widavsky, as quoted by (Winarno, 2012), define public policy as hypotheses containing early conditions and predictable consequences. Public policy must be distinguished from other forms of policy, such as privacy policy. The involvement of non-government factors influences this. As quoted by (Agustino, 2016), refer public policy as a relationship between a government unit and its surrounding. Most think that the definition is still ambiguous because what is meant by the public policy can include many things.

\subsection{Policy Implementation}

According to Mazmanian and Sabatier in (Agustino, 2016), policy implementation is implementing necessary policy decisions, usually in-laws. However, it can also take the form of critical executive orders or decisions of the juridical. Usually, the decision determines the issue to be faced, expressly mentions the objectives to be accomplished, and many approaches to regulating the implementation phase. Implementation is actions to achieve the objectives outlined in policy decisions. Individuals carry out this action, government officials and private.

According to (Nugroho, 2017), there are two options to implement in policy implementation: directly implementing it in programs and developing derivative policies or derivatives of the policy. Therefore, the implementation of Nugroho's policy is two options, the first of which is directly implemented in programs and the second option through policy formulation. According to (Dunn, 2003), policy implementation is implementing control of policy actions within a particular time. Based on the above understanding, policy implementation is implementing policy action control within a particular time. Then, (Winarno, 2012) explained that policy implementation is a legal administration means where many people, procedures, organisations, and techniques work to make policies to accomplish the desired outcome or objectives. 


\subsection{Policy Implementation by George Edward III}

George Edward III on (Widodo, 2008) defined policy implementation as a stage in the policy process between policy preparation stages and the results or consequences arising from the policy (output, outcome). George Edward III's frame of mind that a policy was implementing demanded compliance from the executives to the government's provisions (policymakers).

Thus, this research used the idea of the implementation of George Edward III. Following George Edward III's idea in (Widodo, 2008), the policy's implementation is an action performed by the government to accomplish the policy decision's target. Nonetheless, in making policies, the government need to review whether the policy can harm the community. It aims so that a policy does not conflict with the people, let alone its drawback.

To answer the question, Edward asked four factors that play an essential role in successfully implementing. Elements that affect policy implementation's success are communication, resources, disposition, and bureaucratic structure (Widodo, 2008).

Gambar 1. Model Implementasi George C. Edward III

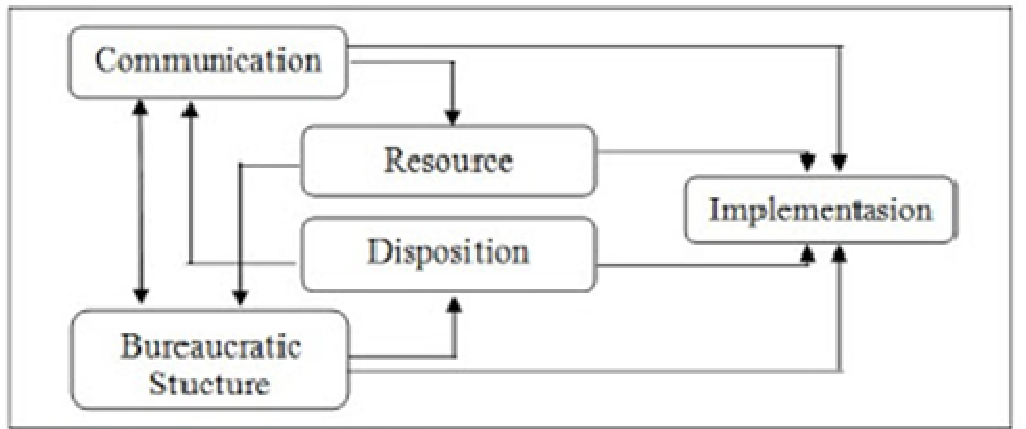

Edward sees policy implementation as a dynamic process, where numerous elements relate to each other and affect policy implementation. These elements require to show so understand how these factors affect implementation. Therefore, Edward emphasised that the implementation study must first be asked two main questions, namely:

1. What are the prerequisites for policy implementation?

2. What are the main factors in the success of policy implementation?

To answer the question, Edward asked four factors that play an essential role in successfully implementing. Factors that influence policy implementation's success or failure are communication, resources, disposition, and bureaucratic structure (Widodo, 2008).

\section{Research Method}

\subsection{Type of Research}

The method used in this research is qualitative. Qualitative research in question recognises what research subjects experience holistically in a descriptive way in language and speech in a context, mostly natural, by using different natural methods. (Moleong, 2013). Furthermore, this research uses descriptive qualitative research to collect detailed actual information that describes existing symptoms, identifies problems, or examines applicable conditions and practices.

\subsection{Type and Source of Data}

The type of data contained in this study based on the source using primary data. Primary data is data obtained by field surveys that use all original data collection methods. The primary data comes from data collected by researchers (Kuncoro, 2013). The primer data in this study are observation, documentation, and interview data.

\subsection{Data Collection Methods}

In qualitative research, the data collected in this study in the form of written or spoken words from people and observable behaviour, then the method used for the process of data collection in this research is:

1) Interview

(Nurgiyantoro, 2012) suggested that the interview method is the process of receiving information for this study purposes utilising question and answer while having direct interaction between researchers and informants or interviewees, with or without guidelines for interviews, where researchers and respondents are engaged a rather long social life.

2) Observation

Observation is an effort to collect data when researchers go directly to the field to observe individuals behaviour and activities at the research site (Creswell, 2014). 


\subsection{Data Analysis}

According to Bogdan \& Taylor, qualitative data analysis is an effort made by working with data; organising information; filtering it into workable units; incorporate them; finding and recognise patterns; revealing what is essential and learned; deciding what means to others (Moleong, 2013).

Data analysis is the final process in qualitative research (Creswell, 2014). According to (Creswell, 2014), there are several steps in analysing the data as follows:

1. Process and queue data for analysis. This step included transcribing interviews, screening materials, understanding field data, or filtering and organising the data into various types depending on the data source.

2. Read the complete information. In this stage, write general ideas or specific notes about the data obtained.

3. Analyse the detail by coding data. Coding is the phase of analysing material and data into a fragment of writing before interpreting it.

4. Apply the coding process to describe the settings, people, categories, and themes to be analysed.

5. Shows how these descriptions and themes will be represented in a qualitative narrative or report.

6. Interpret or interpret data.

Those steps in qualitative data analysis will be used in this study. In this study, the data obtained in the interview transcript then got coded, sorted the themes resulting from the findings, and subsequently carried out data interpretation.

\section{Results}

\subsection{Policy Implementation based on George Edward III}

George Edward III's view on policy implementation led to stages in the policy process between policy preparation stages and the results or consequences caused by the policy (output, outcome). George Edward III considered that a policy in its implementation demanded compliance from the executives to the government's provisions (policymakers). Implementing the Tuban Beach Tourism Development Policy can be influenced by several interconnected variables, as stated in George Edward III's theory. Some of these variables include:

1. Communication

The success of policy implementation requires that implementors know action need to be taken, where the policy's objectives and objectives must be delivered to the object group. Based on this, communication is needed to realise the implementation of existing policies. Communication is essential in policy implementation, considering that effective policy implementation arises when decision-makers already understand what action needs to be taken. Knowledge of what will be done can run if communication goes well so that every action and regulation of implementation need to be transmitted to the people concerned. Similarly, the Implementation of the Tuban Beach Tourism Development Policy implemented by the implementers shows that it has supported good communication. In this case, the government establishes good cooperation and communication with POKDARWIS (Tourism Awareness Group) and MSME implementers in the Kelapa Beach Region.

The interview results showed that the government has been quite clear in conveying information with related parties in implementing the tourism development policy of Tuban Beach. Communication internally is done through meetings or deliberations, to the communication directly through WhatsApp on smartphones. Besides, communication is also conveyed to the public through various communication channels, both managed directly by the government and cooperated with external parties. In tourism promotion, the government has tried to introduce Kelapa Tuban Beach to the community. The promotion is done in two ways, namely impersonal communication or marketing communication conducted by tourists directly through recommendations and reviews that have been felt. The second is interpersonal communication or marketing communication through advertising and various other forms of promotion, such as attending exhibitions and making tourism brochures. In detail, the government's communication media is quite diverse, namely face-to-face media (interviews), filling out questionnaires, brochures on the development of Kelapa Beach, newspaper/magazine media, and online media. The government communicates consistently in developing Coconut Beach tourism by routinely monitoring directly (jumping into the field) or indirectly (monitoring through online data or social media-related parties).

2. Resources

Implementing a policy needs to be supported by adequate resources, human resources, and non-human resources such as equipment resources and financial resources.

a. Human Resources

Human resources have a critical part to play in achieving an organisation's goals. Therefore, adequate human resources critical in the organisation. At the tourism policy level, the Tourism and Sports Office of Tuban Regency backed by officials who have competencies in their 
respective fields. The availability of the number of implementers is adequate or sufficient for the tourism development of Kelapa Beach, for example, POKDARWIS members and management parties who considered to have enough members. The executives have a reasonably good competence but still needed monitoring from the village and tourism parties to develop Kelapa beaches to be better and more in demand.

b. Financial Resources

The budget is needed to smooth policy financing so as not to hinder the policy process. The interview results showed that the budget for a while is still obtained by selling tickets/entrance tickets, parking money, and kiosk rental in Kelapa Beach.

c. Equipment Resources

Facilities and infrastructure in the resources are all available facilities and infrastructure for implementing a policy and used to support directly and related to the tasks set. Based on the interview results, the available infrastructure is excellent and qualified tourist attractions.

\section{Disposition}

Disposition is a tendency of policy implementers' behaviour or characteristics to play an essential role in realising implementation policies following the targets or objectives. Important characters that have got to be had by policy implementers like honesty and high commitment. Disposition is the implementer's attitude and commitment to the program or policy, especially the implementers who become the program implementers. Thus the disposition is closely related to the commitment of policy implementers. Based on the interview results, the parties involved have held firm commitments and are willing to implement Kelapa Beach's development. The executives' attitudes or related parties have been open to each other and willing to work together to increase visitors' attractiveness in Kelapa Beach's development.

The successful implementation of tourism development policies depends heavily on the public's tendency to respond to policies and implementation. Tourism policy in its development must involve the public, especially local people in tourist areas. This follows the model of community-based tourism used by researchers in looking at tourism in the Tuban Regency. One of the executives' efforts or related parties in involving the community in the development of tourism Tuban Beach is to provide opportunities for the community around the Kelapa beach to open a business (trade) in the coconut beach area. It also provides employment opportunities for productive age people in the coconut beach area as staff, ticket keepers, and others.

4. Bureaucratic Structure

The bureaucratic structure is in a vital position of implementing policies has a significant effect on policy implementation. The organisational structure is expected to have productive and effective and efficient human resources. The bureaucratic structure is based on the duties and responsibilities that govern the flow of work and policy implementation. The interview results show that the organisational structure is well organised, and the members have carried out their duties according to their respective fields. The operational procedure has been running following the planned procedures and adjusted to the ability.

\section{Conclusions}

Based on the analysis results, the Implementation of Tourism Development Policy of Tuban Beach has been running well. It was reviewed based on George Edward III's theory that saw successful implementation based on four aspects: communication, resources, disposition, and bureaucratic structure. Reviewing communication shows that the government establishes good cooperation and communication with POKDARWIS and implements MSMEs in the Kelapa Beach Region. The government has been quite clear in conveying information with relevant parties to implement the tourism development policy of Tuban Beach. Communication is carried out between internal and external parties, such as conducting Kelapa Tuban Beach's introduction to the community through promotion both with face-to-face media (interviews), filling out questionnaires, brochures on the development of Kelapa Beach, newspaper/magazine media, and online media. Communication is carried out consistently by routinely monitoring both directly and indirectly.

Reviewed based on resources, especially human resources, it is seen that the availability of the number of implementers, both POKDARWIS members and the management, is adequate or sufficient for the process of tourism development of Kelapa Beach. The executives have a reasonably good competence but still required monitoring from the village and tourism parties. Furthermore, the available infrastructure resources are excellent and qualified tourist attractions. In contrast, budget resources showed while only obtained through the sale of tickets/entrance tickets, parking money, kiosk rental in Kelapa Beach.

Reviewed from the disposition shows that the parties involved are firmly committed and willing to implement Kelapa Beach's development. The executives also showed an open attitude and were willing to cooperate in the development of Kelapa Beach. The successful implementation of tourism development policies 
depends heavily on the public's tendency to respond to policies and implementation. In this case, the government limits the community in developing Tuban Beach tourism by providing opportunities for people around the coconut beach to open businesses (trade) in the coconut beach area. While reviewed from the bureaucratic structure, the organisational structure is well organised, and the members have carried out their duties according to their respective fields. The operational procedure has also run according to the planned procedures and has adjusted to each's ability.

\section{References}

Agustino, L. (2016) Dasar-dasar Kebijakan Publik Edisi Revisi. 8th edn. Bandung: Alfabeta.

Creswell, J. W. (2014) Research design: qualitative, quantitative, and mixed methods approaches. 4th-ed edn. United Kingdom: Sage Publications, Inc.

Dunn, W. N. (2003) Pengantar analisis kebijakan publik. 2nd edn. Yogyakarta: Gadjah Mada University Press.

Edwards, G. C. (1980) Implementing public policy. Washington, D.C.: Congressional Quarterly Press, (C)1980.

Fadelan, Darmawan, A. and Widodo, D. (2020) 'Overview of Fish Catchment Policy in Improving Eco-Friendly and Economy in Lamongan', Public Policy and Administration Research, 10(12), pp. 29-32. doi: 10.7176/PPAR/10-12-05.

Karnadjaja, D. et al. (2020) 'Study of Tourism Governance in Gunungkidul (An Initiative Proposing Guidelines for Beaching Tourism Governance)', Public Policy and Administration Research, 10(11), pp. 21-31. doi: 10.7176/ppar/10-11-04.

Kuncoro, M. (2013) Metode Riset untuk Bisnis dan Ekonomi. 4th edn. Jakarta: Erlangga.

Moleong, L. J. (2013) Metode Penelitian Kualitatif. Revisi. Bandung: PT. Remaja Rosdakarya.

Mulyadi, D. (2015) Studi Kebijakan Publik dan Pelayanan Publik Konsep dan Aplikasi Prosedur keijakan \& Pelayanan Publik: Konsep dan aplikasi prosedur kebijakan. 1st edn. Bandung: Alfabeta.

Nugroho, R. (2017) Public Policy. Jakarta: Elex Media Komputindo.

Nurgiyantoro, B. (2012) Penilaian Pembelajaran Bahasa. Yogyakarta: Gadjah Mada University Press.

Pitana, I. G. and Gayatri, P. G. (2005) Sosiologi Pariwisata. 1st edn. Yogyakarta: ANDI.

Wahab, A. S. (2015) Analisis Kebijakan: Dari Formulasi Ke Penyusunan Model-Model Implementasi Kebijakan Publik. 1st edn. Jakarta: Bumi Aksara.

Widodo, J. (2008) Analisis Kebijakan Publik: konsep dan aplikasi analisis proses kebijakan publik. 2nd edn. Malang: Bayumedia Publishing.

Winarno, B. (2012) Kebijakan Publik: Teori, Proses, Dan Studi Kasus. 1st edn. Yogyakarta: CAPS. 